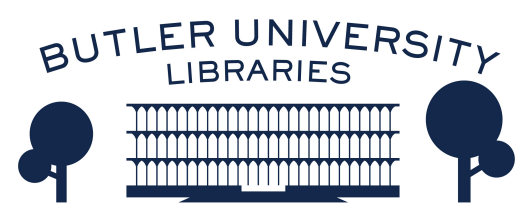

Journal of Hindu-Christian Studies

January 2007

\title{
Book Review: "Fr. Bouchet's India: An 18th Century Jesuit's Encounter with Hinduism"
}

Daniel Jeyaraj

Follow this and additional works at: https://digitalcommons.butler.edu/jhcs

Part of the Religion Commons

\section{Recommended Citation}

Jeyaraj, Daniel (2007) "Book Review: "Fr. Bouchet's India: An 18th Century Jesuit's Encounter with Hinduism"," Journal of Hindu-Christian Studies: Vol. 20, Article 19.

Available at: https://doi.org/10.7825/2164-6279.1394

The Journal of Hindu-Christian Studies is a publication of the Society for Hindu-Christian Studies. The digital version is made available by Digital Commons @ Butler University. For questions about the Journal or the Society, please contact cbauman@butler.edu. For more information about Digital Commons @ Butler University, please contact digitalscholarship@butler.edu. 
equally well for supporting Locklin's argument, might this mitigate crucial differences between and religious commitment to particular traditions? Locklin's answer is complex and in many ways uncompromising. Although he considers himself a "theoretical inclusivist" and a "practical pluralist," he also feels both positions to be a little too clean and, more to the point, come with a cost to religious commitment. While inclusivist and pluralist views may soften institutional commitment, religious exclusivism, on the other hand, can reap disastrous results. The solution, as Locklin sees it, emerges within the realm of mystery. Bringing his book's argument full circle, Locklin notes that the mystery of inter-religious relationships, of the coming together of outsiders, as in any relationship, is central to the religious truths presented by both Shankara and Augustine. These theological mysteries, uniting apparent irreconcilables, echo the mystery of faith when conceived of as an encounter and relationship with an Other. The mystery and challenge of interreligious dialogue is thus not simply a biproduct of living in a shrinking global community but, as Locklin constructs it, the broadest of concentric circles surrounding the mystery and sacrality into which committed relationships propel us. The core mystery of faith as encounter with an Other, deepened and clarified by the challenges of institutional commitment, plumbs further depths with committed inter-religious exchanges - not interreligious conflations. As Locklin puts it, "if to be spiritual is to necessarily to be religious, then it is also true that to be religious is necessarily to be in dialogue."

Corinne Dempsey

University of Wisconsin - Stevens Point

\section{Fr. Bouchet's India: An $18^{\text {th }}$ Century Jesuit's Encounter with Hinduism. Francis X. Clooney. Chennai/Inida: Satya Nilayam Publications, 2005, pages viii +110}

IT is believed that as long as a person is remembered that person is not dead. One of the major challenges of a historian is not only to keep the memories of people alive, but also to recover and enliven the memories of those whose life and works were not remembered or forgotten. Whoever recovers these memories and provides them afresh to the contemporary generation of peoples deserve our congratulation. Father Francis X. Clooney, a Jesuit priest from New York, and the Parkman Professor of Divinity and Professor of Comparative Theology at the Harvard Divinity School in Massachusetts, has regained the memories of Jean Venant Bouchet (1655-1732).

Father Clooney's unique abilities to read and interpret the Tamil and French writings by Bouchet have enabled him to highlight the manifold contributions of Bouchet to the people of Tamil Nadu and Europe of his time. Originally, he went to Thailand, and desired to serve there. Sudden political changes forced him out of Thailand. He was a French Jesuit. Since 1689 he traveled extensively in the geographical area that is now known as Tamil Nadu, Andhra, Karnataka, and Kerala. He became a member of the celebrated Madurai Mission established by the well-known Jesuit missionary Roberto de Nobili (1577-1656), and lived mostly in Pondichery, the principal French Colony (1673/4-1954) on the southeastern Coromandel Coast of India. He learned the Tamil language and interacted with the Tamil people. They in turn appreciated his friendship and trust; therefore they disclosed to him the deepest aspects of their religious beliefs and practices, legal traditions, and socio-cultural behavior patterns. He learned not to compare the sociocultural settings of the Tamil people with that of the French or other Europeans; instead he recorded his observations and opinions that form the core of Father Clooney's present book.

Father Clooney masterfully examines Bouchet's letters written in French and his 
religious treatises written in Tamil. He presents his findings in four sections: the first section describes the complex social and ecclesiastical context in which Bouchet lived. He followed the indigenous mission methods developed by $\mathrm{De}$ Nobili. But he courageously countered the verdict of Cardinal T.M. de Tournon who ordered the Jesuits of the Madurai Mission to give up several identity-defining rites of the Tamil Roman Catholic Christians. The second section of Clooney's book points out Bouchet's observations of Indians and their plural societies, his descriptions of the Christian mission among the Tamil people, his efforts to educate his contemporaries in France, and his views about the living faiths of the Tamil people in their life settings. It seems that Bouchet was not fully aware of the intellectual aspects of Sanskritbased and Brahmin-dominated philosophical systems such as the Advaita ("No-Two-ness"). The Tamil people whom Bouchet knew were not concerned with theoretical and philosophical questions of their metaphysical origin and end; rather they sought answers for the joys and sorrows of their life in concrete folk religiosity. Only towards the end of the eighteenth century European scholars expounded the diverse expressions of many Indic religions under the less-definable term "Hinduism." Similarly, Father Clooney believes that Bouchet certain aspects of "Hinduism." After all, Bouchet was not an Indologist. His primary missionary vocation led him to study the religious worldviews, attitudes, beliefs and practices of the people with him he interacted. His findings, however, contain a treasure trove of social and religious details that preserve the memories of the people of his time which otherwise might have been lost for ever.

The third section of Clooney's book deals with five theological and pastoral texts in Tamil that were probably written by Bouchet. Just like De Nobili, Bouchet uses numerous Sanskrit loan words to describe Roman Catholic views on Mother Mary, proper social and moral behavior of Roman . Catholic converts; spiritual consolation available to them, and on good death. Clooney knows the insider and outsider views of these topics, and summarizes them succinctly. The fourth and final section of Clooney's book introduces the readers to the influence and relevance of Bouchet's works for the Roman Catholic Christians in general, the Jesuits in particular, and for others who wish to study themes related not only to indigenization but also to South India and its people in late seventeenth and early eighteenth centuries.

It is obvious that Bouchet was only one of the European missionaries and Tamil Christians who together worked for the emergence of an Indian Christianity. Therefore it is important to study Bouchet's contributions along with the achievements of his contemporaries in Tamil country. German Lutheran missionaries such as B. Ziegenbalg (1682-1719), J.E. Gründler (1677-1720), B. Schultze (1689-1760), and Tamil Lutheran leaders such as Aaron (ordained as the first Tamil pastor in December 1733), and Rajanaikan (the founder of the Tamil Lutheran Church in Tanjore, the capital city of the Kingdom of Tanjore), and others worked for the growth of Tamil Christianity. Indians hosted the European missionaries and learned from them. European missionaries lived among Indians and learned from them. Their life and joint services remind us of our interdependence.

Original studies on Christian missionaries and their interactions with native peoples of various cultures will correct the stereotype and judgmental ideas about Christian missionaries that are currently prevalent in the post-Christian west. Common assumptions that view Christian missionaries as destroyers of the cultures of native peoples of the general opinion that the local people were forced into Christianity against their will and pleasure should be addressed and revised. Only careful analysis of missionary records of individual missionaries and unbiased listening to the testimonies of the hosts of the European missionaries and their descendents will bring out nuanced meanings of cross-cultural missionary interactions. Such a study will surely promote intercultural learning and mutually enriching awareness. Father Clooney's example deserves our congratulation.

Daniel Jeyaraj

Andover Newton Theological School 